\title{
The role of evolution and invention of tradition in identity and the built environment
}

El papel de la evolución y la invención de la tradición en la identidad y el entorno construido

O papel da evolução e da invenção da tradição na identidade e no ambiente construído

Keywords $\mid$ Palabras clave $\mid$ Pallaviras chave

Memory, Authenticity, History, Architecture, Urbanism

Memoria, Autenticidad, Historia, Arquitectura, Urbanismo

Memória, Autenticidade, História, Arquitectura, Urbanismo

\begin{abstract}
Resumen | Resumo
Tradition is often presented as simply the past and a static phenomenon. This view can be shared by some supporters of tradition in architecture and urbanism, leading to a valorisation of literal past form and detail. Social analysis of tradition acknowledges that it is a more complex and not static phenomenon. At the same time, the concept of the invention of tradition is widely used to discredit tradition itself. This paper departs from the work of Halbwachs and subsequent studies on collective identity, Boyd and Richerson on Dual Inheritance Theory, Shils on the ubiquity of tradition and Cohen on the sociology of identity, amongst others. This is combined with case studies in the evolution and invention of tradition. The paper presents the applicability of changing and invented traditions that foment social cohesion and how their use in design can respond to community identity.
\end{abstract}

La tradición se suele presentar simplemente como el pasado, como un fenómeno estático. Esta opinión pueden compartirla algunos defensores de la tradición en la arquitectura y el urbanismo, llevándolos a valorar las formas y detalles literales del pasado. El análisis social de las tradiciones indica que se trata de un fenómeno más complejo y nada estático. Al mismo tiempo, el concepto de invención de la tradición se utiliza frecuentemente para desacreditar a la propia tradición. Este artículo toma como punto de partida la obra de Halbwachs y otros estudios posteriores sobre la identidad colectiva, los de Boyd y Richerson sobre la teoría de la herencia dual, los de Shils sobre la ubicuidad de la tradición y los de Cohen sobre la sociología de la identidad, entre otros. A esto se añaden los estudios monográficos sobre la evolución y la invención dentro de la tradición. El artículo presenta la aplicabilidad de las tradiciones cambiantes e inventadas, que fomentan la cohesión social, y cómo su uso en los proyectos puede responder a la identidad comunitaria. 
A tradição é frequentemente apresentada como sendo simplesmente o passado e um fenómeno estático. Esta visão pode ser partilhada por alguns defensores da tradição na arquitectura e urbanismo, levando a uma valorização da forma e detalhe literais do passado. A análise social da tradição reconhece que se trata de um fenómeno mais complexo e não estático. Ao mesmo tempo, o conceito de invenção da tradição é amplamente utilizado para desacreditar a própria tradição. Este artigo parte do trabalho de Halbwachs e de estudos subsequentes sobre a identidade colectiva, de Boyd e Richerson sobre a Teoria do Património Dual, de Shils sobre a ubiquidade da tradição, e de Cohen sobre a sociologia da identidade, entre outros. Isto é combinado com estudos de caso sobre a evolução e invenção da tradição. $\mathrm{O}$ artigo apresenta a aplicabilidade das tradições mutáveis e inventadas que fomentam a coesão social, e como a sua utilização na elaboração de projectos pode dar uma resposta à identidade da comunidade.

\section{Introduction and methodology}

Tradition is often regarded as a brake on progress, a dependence on the past that inhibits innovation and advancement into a better future. This originated in the Enlightenment (Diderot and d'Alembert 1993) and found its full expression in the iconoclasm of early Modernism in the first decades of the twentieth century (Chipp 1970). Many early-twenty-first-century artists and architects are the inheritors of the ideals of early Modernism and, while the counter-traditional rhetoric has diminished, any apparently sentimental attachment to the past continues to be censured (Vidler 1976: 4).

In the latter part of the twentieth century, a revived interest in tradition found its way into the mainstream of art and architecture. Conservative purchasing power in the studio arts had maintained a connection with the tradition of representation (Gowing and Sylvester 1990) and a few architects, mostly supported by wealthy private clients, had maintained the classical tradition (Archer 1985), but these had all been ignored as an aberration or throwback by influential critics. The entry of these traditions into the mainstream took the more radical forms of Pop Art, Hyper-Realism and Post-Modernism, but still remained as minority movements. In architecture, Post-Modernism lasted only some fifteen years, from the mid-70s to the economic crisis of the early 90s. Many architects returned then to Modernism (Farrell 2004; Farrell 2008; Latham and Swenarton 2002), but some had already taken a more literal turn to the history of classicism or turned to it away from the deliberate eccentricity of Post-Modernism (John 2002).

Both the continuing adherents of Modernism, in their distrust of tradition, and the New Traditionalists, in their faithful adoption of consistent period-specific forms, often see tradition as an aspect of history. This interpretation can be taken from the dictionary definitions of "tradition". In English, the main definition is (there are a number of sub-sets): "a belief, principle, or way of acting that people in a particular society or group have continued to follow for a long time, or all of these beliefs, etc. in a particular society or group" (Cambridge Dictionary). In Spanish, principally (also with sub-sets): "transmisión de noticias, composiciones literarias, doctrinas, ritos, costumbres, etc., hecha de generación en generación" (Diccionario de la Lengua Española. Real Academia Española). The nature of transmission is not defined but, if the assumption is that it must be as a repetition of immovable past events, that past is subject to interpretation but always factually verifiable. This is the assumption for Modernists, for whom history was always something of interest, but only as a spur to invention or a justification for change by reference to past change (Giedon 1941). It is also assumed by the New Traditionalists, for whom historically accurate detail and typological consistency can be seen as measures of quality. By aligning tradition closely with history, however, both viewpoints misinterpret tradition. A better understanding of tradition will show how we can relate positively and creatively to the past. 
Beyond word-definition, the starting point in any discussion of how the past influences the present and the future must be entirely logical. While we all live unavoidably in the present, that present is a moving but infinitesimal division between a past that has happened and cannot be changed - history - and a future that is always to some degree uncertain as it does not yet exist (Mellor 1998). We have to navigate the future for all decision-making but the only tools we have available originate in the past. We can use our imagination and inventiveness to do this, but our point of reference is always the past, albeit often immediate. This is very effectively illustrated by representations of past science fiction, in spite of their role as deliberately inventive predictions, their time of origin remains abundantly clear (Fig. 1).

From logic we can turn to human perception. We rely on our memories for all that we do, think and speculate and those memories can only be of the past. Those memories, however, are not an orderly historical sequence or a verbatim recording of events. They are jumble of recollections brought to the fore in response to some desire to act or consider and in some way apparently relevant to those actions or considerations and, indeed, each recollection is a new memory to be called upon another time (Fernyhough 2012: 8). We use these memories for all our speculation and anticipation of the future into which we move irreversibly. Memories are not history and, similarly, most commentators on tradition also specifically distinguish it from history. We will return to this theme. While memories are individual, traditions are by their nature communal and are an entirely consistent phenomenon in society, to this day. The role of tradition is analysed in sociological and anthropological studies and from these it is possible to see tradition as a positive and evolving phenomenon and an essential part of social identity.

\section{Collective memory}

Unlike custom, with which it is often confused, tradition is not just a matter of habit nor can it be solitary; it is a deliberate communal activity. The community can be anything from a family to a nation, or a club to a culture. One way or the other, it is a collection of people that share one or more traditions and these are passed down from generation to generation within the community. These will be aspects of the past and a tradition is a recollection of that past. It is a collective memory.

The idea of a memory held and shared collectively - the collective memory - originated in the work of Maurice Halbwachs. He was a pupil of Emile Durkheim, founder of the academic discipline of sociology. Halbwachs points out that: "it is in society that people normally acquire their memories. It is also in society that they recall, recognise, and localise their memories (...) It is in this sense that there exists a collective memory and social frameworks for memory" (Coser 1992: 38). He goes further and announces that "we should henceforth renounce the idea that the past is in itself preserved with individual memories" (Coser 1992: 173), and asserts that "collective memory must be distinguished from history” (Coser 1992: 222). Logically, from these two statements therefore, memory of the past (as there is only memory, he must mean all memory) does not "preserve" the past. The collective memory of the group or community is linked by Halbwachs quite specifically to place, "the group's image of its external milieu and its stable relationship with this environment becomes paramount in the idea it forms of itself, permeating every element of its consciousness, moderating and governing its evolution" (Olick et al $2011: 142$ ). This seems to be a very succinct description, not only of tradition but how traditions frame the identity of communities. He is clear on both the relationship between collective memory and tradition: "we call collective memory that totality of traditions", (Coser 1992: 141) and the relationship between traditions and group identity, "every social group derives its spiritual unity from the traditions that constitute the specific content of the collective memory" (Olick et al 2011: 152).

Collective memory has become an academic sociological discipline in itself. It is interesting to observe how this has not leaked through into the debate on architecture and urbanism, so averse has the mainstream been to any concept

Figure 1. Science Fiction Future City, 1940s (Planet Stories, Summer 1946, Leyden Frost, Wikimedia Commons)

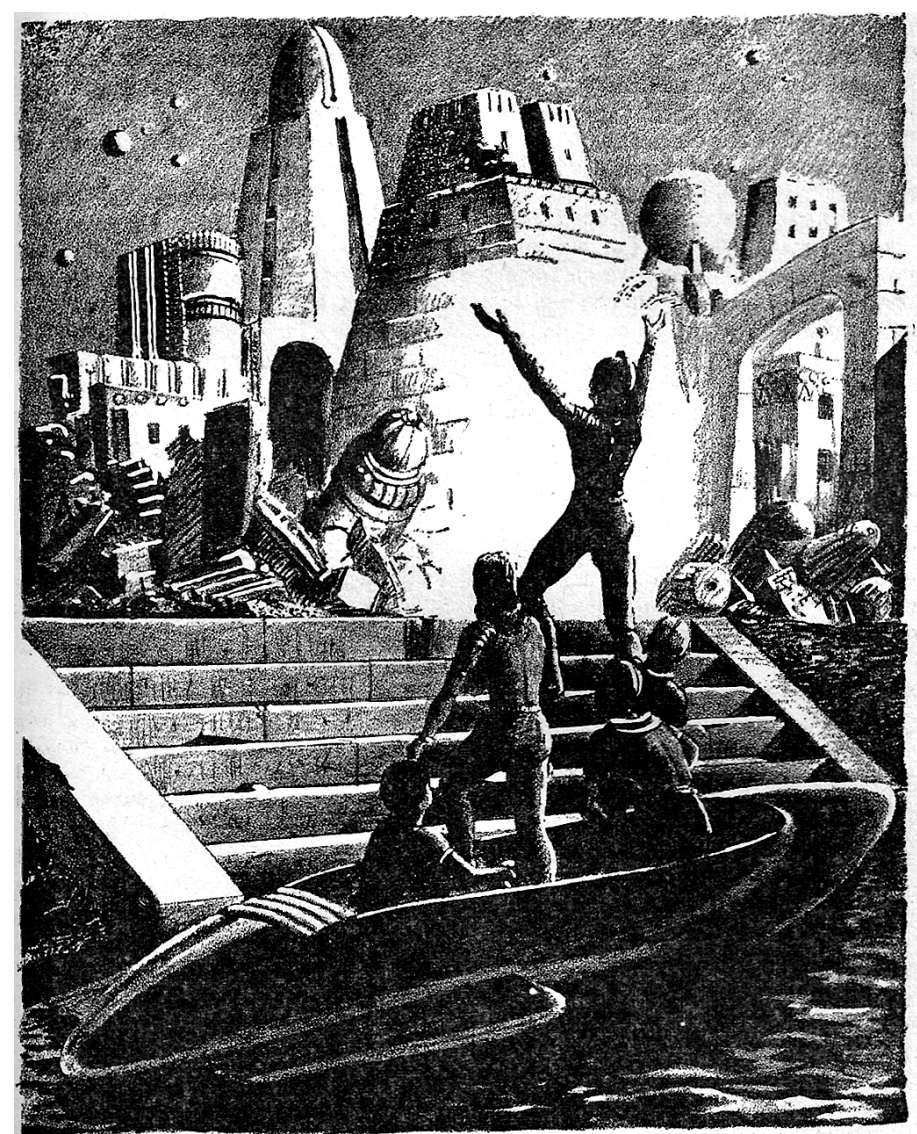


of tradition. One exception was Aldo Rossi who, in 1966 in The Architecture of the City, quotes Halbwachs and states that, "the city is the locus of the collective memory" (Rossi 1982: 130). As much of the academic work on collective memory demonstrates, this is an over-statement. There are many other aspects and manifestations of collective memory and, therefore, tradition, but the physical environment is clearly one of them. It is revealing, however, to examine these other manifestations of collective memory and traditions and see what light they cast on tradition in architecture and urban design.

\section{Dual Inheritance Theory}

As Aristotle famously said, "man is by nature a social animal" (Aristotle 1990: 1253a) and this can be extended to the way that communities know they are communities. In the words of Marc Bloch, "every social group derives its spiritual unity from the traditions that constitute the specific content of the collective memory" (Bloch 1925). If the fundamental aspect of the human being, the homo sapiens sapiens, is to exist in communities, as all creatures do not share this characteristic, this will have an evolutionary basis.

We can turn to the work of Robert Boyd and Peter Richerson, respectively an anthropologist and a biologist, to demonstrate how fundamental the passing down of cultural traditions are both to our species identity and our success as a species. Boyd and Richerson use the principles of Darwinian evolution in a detailed analysis of how societies have developed. They recognise that this is not a perfect analogy, biological evolution typically spans millennia and social evolution, being entirely cognitionbased, can move at a much faster pace. Their studies are based on the principles of evolution only in as much as "both systems create patterns of heritable variation" (Boyd and Richerson 1985: 158) and that "culture is a socially transmitted heritage" (Boyd and Richerson, 1985: 33). Their analysis is called "Dual Inheritance Theory", on the basis that biological and cultural evolution have been twospeed partners in the making of mankind into what it has become.

As with biological evolution, the passing of information over generations in a community, cultural transmission or inheritance, "is an efficient shortcut to trial-and-error learning. By imitating the cultural rules of others, individuals can avoid the cost of learning" (Boyd and Richerson 1985: 80), and its efficiency is the reason for its success. It is unlike learning by observation, often from parent to offspring, of other species as it is community based, is assessed intelligently and "allows individual learning to be selective. Individuals can learn opportunistically when it is likely to be more accurate or less costly and imitate when conditions are less favourable" (Boyd and Richerson 2005: 44). The significance of cultural transmission cannot be underestimated. "These accumulated cultural traditions allow us to exploit a far wider range of habitats than any other animal, so that even with only hunting and gathering technology, humans became the most widespread mammal on earth" (Boyd and Richerson 2005: 52).

Sociology, biology and anthropology demonstrate clearly that traditions, the way of acting and beliefs that people in a particular society or group have continued to follow for generations, are both fundamental to the way that humans have evolved and the success of that evolution that allows us to become civilisations and builders, as well as the foundation of our identity as social groups that cements the communities that make possible the collective action required for the creation of civilisation and act of building. Traditions, expressed through collective memory and with cultural transmission, are a key part of what makes us human.

\section{The Ubiquity of Tradition}

If traditions are indeed an essential part of being human, it may seem strange to claim, as many do, that we are in a post-traditional age (Heelas et al 1995). In effect, that we are losing one of the essential characteristics of humanity in order in some way to be modern. This is, however, a common view in some circles. Jürgen Habermas proposed that, "social modernity can develop its own evolutionary dynamism apart from the historical transmission of tradition" (1987: 72). Anthony Giddens said, "tradition is tradition in sham clothing and receives its identity only from the reflexivity of the modern" (1991: 38). This will be familiar in the arts from early-twentieth-century Modernism, summarised by Le Corbusier: "There is no longer any question of custom, nor of tradition" (1923: 11 ), and is carried through to statements like that of the German architect Volkwin Marg: “These days we've lost tradition” (Rautenberg, 2008: 67).

Studies of tradition as a phenomenon, as a contrary to an ideological stance, reveal their continuity in modern society. Edward Shils produced the most comprehensive account in his seminal book, Tradition, and identifies the consistency of traditions in most modern institutions, in the form of what he calls, "normative traditions". He finds them in science, the objective nature of which is often presented as the antithesis of tradition, "Representing the state of correct belief in, let us say, mathematics or chemistry, their assertion both assumes their correctness and recommends their acceptance. This is the barest normative minimum of any tradition or belief (...) Most traditions of belief are normative in this sense" (1981:24). He goes on to say, "the first conception of an unsolved problem in the received tradition and the generation of an idea about its solution both depend on the availability of the tradition and its mastery. New knowledge would not be possible without old knowledge" (113). He also identifies 
tradition in literature: "What are called 'classics' have normative consequences within literature and art; they provide models for the aspirations of subsequent authors and artists" (25); and sees tradition as fundamental to all literature: "Any writer can take as his point of reference any other writer, any work, or any type of work of any period. (...) What he cannot do is become a writer without any tradition at all" (160). We can take literature as a proxy for all the arts.

What is clear is that many of our social, religious and intellectual institutions depend for their legitimacy on their traditions, "contemporary societies of the West are linked to those of a century ago by approximations to identity in modes of political life, the organisation of universities, types of religious institutions, beliefs, and ritual, and the legal system" (Shils 1981:33). Shils goes beyond his systematic catalogue of the continued role of tradition (of which the above is just the briefest of summaries) to concur with Halbwachs and Boyd and Richerson on their essential role in human nature: "substantive traditions (... ) the appreciation of the accomplishments and wisdom of the past $(\ldots)$ as well as the desirability of regarding patterns inherited from the past as valid guides" (21); and continues: "not because they are the exterior manifestation of still unbroken habits and superstitions but because most human beings constituted as they are cannot live without them" (304-5).

\section{Tradition, History and Authenticity}

While traditions may be an essential part of humanity and pervade even modern society, their nature needs to be understood.

There is, as we have discussed, an assumption that traditions are throwbacks or parts of the past that have seeped through to the present creating regrettable impediments to the forward movement of society. This view goes even further into the Enlightenment and Marxist (and indeed early Christian) principle that the direction of history is predetermined (and for the Enlightenment and Marxist view, it is also progressive) and that anyone who gets in the way of this is not just mistaken, but is an enemy of history itself - a much more serious matter. This is captured with chilling precision by the French revolutionary Louis Antoine de Saint-Just, called the "Angel of Death", whose censure alone could mean execution: "in a time of innovation, everything that is not new is pernicious" (SaintJust, 1793). This finds its place from Soviet collectivisation to Pol Pot's year zero.

There is a parallel view that in following traditions you should do so with accuracy to the historical precedents to which you refer. Josef Pieper, from an ecclesiological point of view, sees conformity and consistency from the past as a mark of tradition (1994). Traditionalists in architecture often concern themselves with historical accuracy to, and detailed consistency with, the period which they
Figure 2. Kilboy House, County Tipperary, Ireland, Quinlan and Francis Terry, 2015: Traditional architecture directly taken from historic precedent (Quinlan Terry, photographer Nick Carter)

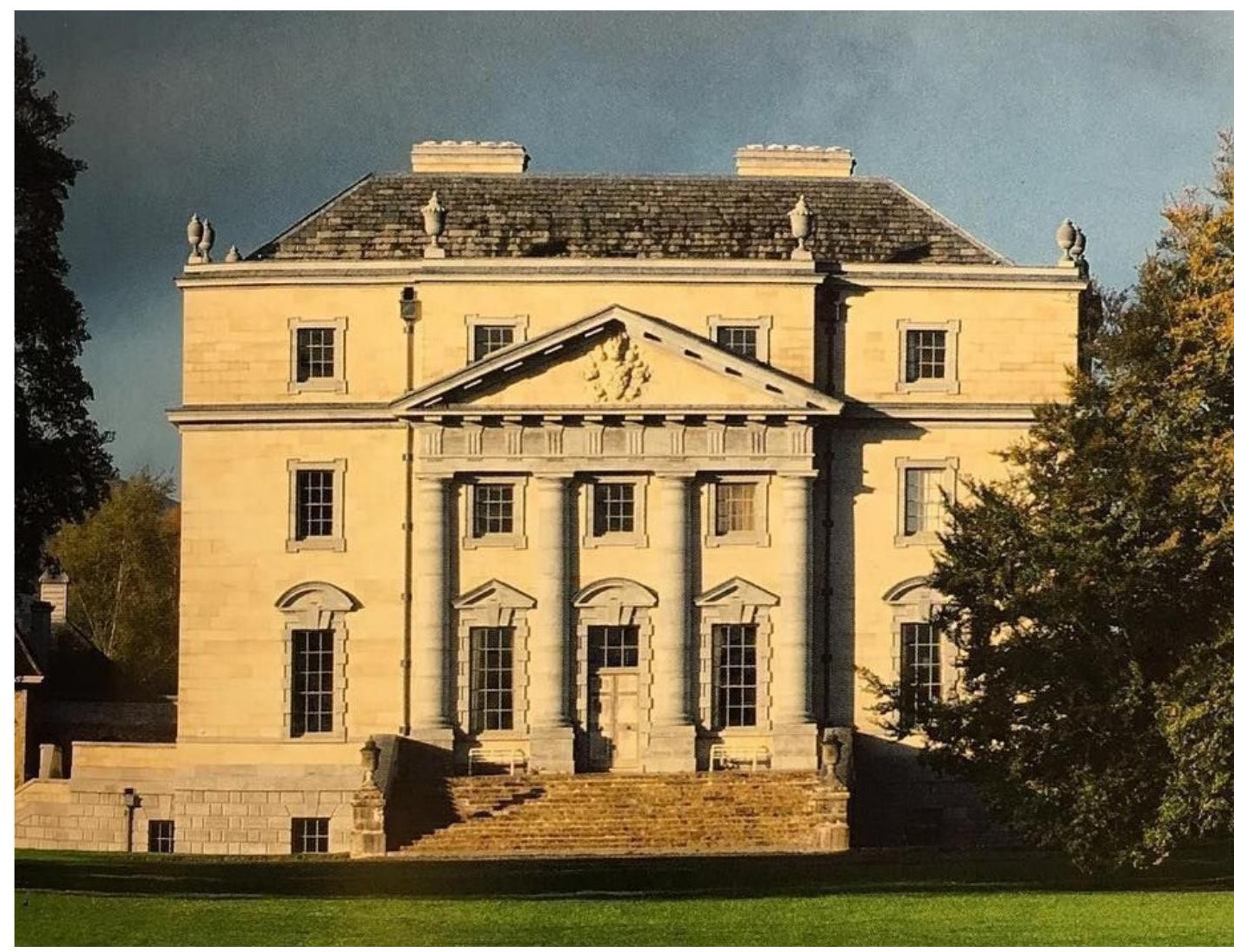


and "bogus" (44). Hobsbawm sees that in such inventions, all too often: "The intention to use, indeed often to invent them for manipulation is evident" (1983: 307).

The issue becomes, how long must a tradition be established for it to be a tradition? The legal definition in such matters as advertising description is measured in generations, usually three or four. Shils raises the issue of what constitutes a generation? A generation in demographic terms, from being born to giving birth, is averaged at something like twenty five years. But traditions are cultural phenomena, not biological, and depend on what constitutes a generation for the community that enacts a tradition. "In a school, for example, where children spend four years, a generation may only be four years long" (Shils 1981: 15). In this case, a tradition may be established in 12 years. For example, "Step Sing" a musical performance at Samford University, Alabama, was established by students in the early 1950s. By 1965 it was accepted as a college tradition (Morris 2018).

Established traditions can also have new features added to them. The Fiesta of San Fermín, in Pamplona, dates back to the $12^{\text {th }}$ century but in 1941 the setting off of the firework, the Chupinazo, accompanied by a crowd display of red scarves, became part of the traditional celebrations and in 1979 local political rotation for the lighting of the firework also became a tradition (Fig. 3).

Traditions are, as Hobsbawm and Ranger affirm, regularly invented. They provide examples: the use of the kilt in modern Scottish society, Bastille Day in France, Trades Union Parades. While they provide a critique of these inventions, they do not mention their potency even when the fact of invention itself is known. The invention of the modern Scottish kilt is based on a real but rather different form of Highland clothing, but is now a powerful symbol of Scottish identity for people with no ethic connections to its origin. Bastille Day or the Fête Nationale was instituted in 1978 on the day of the storming of the Bastille 89 years earlier. It was immediately an important traditional parade for French republicanism. The Tolpuddle Martyrs' Trades Union parade in the UK was instituted in 1922, commemorating the prosecution of early trade unionists 112 years earlier. Within ten years it had become a rallying tradition for the British left wing (Fig. 4). As Halbwachs says, "Society will (...) rely on other traditions that are more closely in tune with present-day needs and tendencies. But it is within the framework of these old notions and under the pretext of traditional ideas, that a new order of values would become slowly elaborated" (Coser 1992: 160). All these invented traditions are united in their attachment to a convincing ancestry; its truth or accuracy is not at issue.

The authenticity of traditions is clearly a complex subject. It is not historic accuracy, longevity or continuity with events. Traditions can emerge rapidly, be invented and augmented. All that seems to matter is that a community accepts them and, to do so, sufficient reference to ancestry to be convincing seems to be all that is necessary.

\section{The expression of tradition}

As Halbwachs confirms, collective memory and tradition are the way relevant communities maintain their identities. This must be in a form that is recognisable to the members of the community (Fig. 5). It will have to be distinct and cannot simply be a wholly functional response to circumstances that would be shared by any community faced with or potentially faced with a similar functional challenge. Traditions, unlike customs, will be visible and frequently symbolic, ceremonial or decorative. Anthony Cohen, a British social anthropologist, in his studies of small Scottish communities, observed that: "People
Figure 5. Hindu Temple, Nottingham, England: A clear visual signal of the identity of a faith community

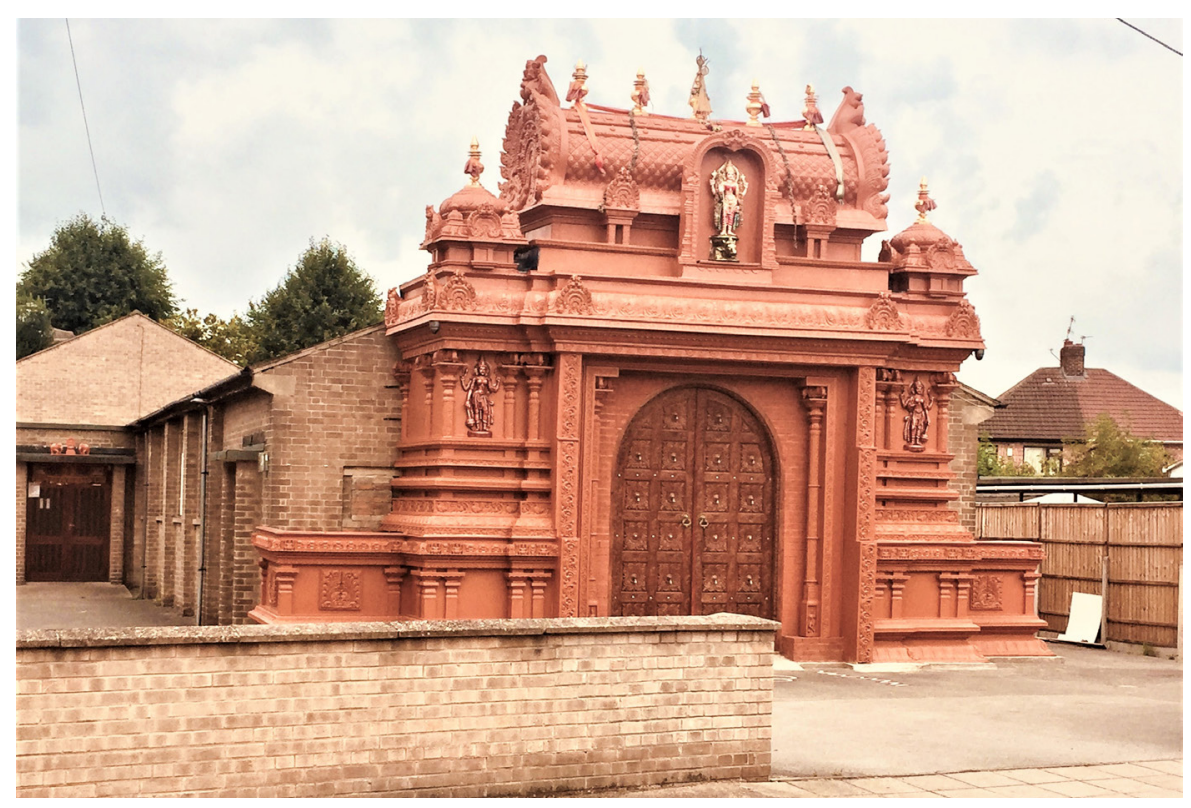


construct community symbolically, making it a resource and repository of meaning, and a referent of their identity" (Cohen 1985: 118).

Halbwachs refers to the attachment "to formulas, symbols, and conventions, as well as to rites that must be repeated and reproduced, if we wish to preserve the beliefs which gave them birth" (Coser 1992: 20). Shils confirms their symbolic role: "The boundaries of a tradition $(. .$.$) are the$ boundaries of symbolic constructions" (1981: 263). Boyd and Richerson identify how "arbitrary but subjectively meaningful cultural symbols evolve from functional indices, as in the elaborate, highly variable dress and diet markers of prestige" (1985: 294).

The traditional markers of community identity can be particularly powerful and centre around key events in the life of the family or society. Celebrations of birth, marriage and death often include both ceremony and distinctive dress. Political events are often marked by parades, uniforms and ceremonies. The enactment of national laws often includes procedures and robes that confirm the community's engagement with their legal system and its authority (Fig. 6).

\section{Characteristics of tradition}

We can now identify certain key characteristics of traditions:

- An essential part of the human condition, individually and as a community.

- Communal accumulated memory that gives identity to the group and to all members of the group.
- As memory, not history, and neither literal nor sequential, but selective, adaptive and eclectic.

- Understood as a tradition by a group and often expressed in display, decoration, ceremony or symbol.

The discussion so far has largely been on tradition as a universal social phenomenon. We can glean from this how it is expressed and how it can be understood and used in the arts and in the built environment.

\section{Art, architecture, traditions and the community}

Once we have removed rhetoric from an understanding of tradition, it can cast a new light on both those who set out to oppose it and those who lay claim to it.

Early modernist authors and poets, tied to the conventions of language and literature, at times acknowledge the continued influence of tradition. The work of Federico García Lorca, who "uses a traditional theme, yet (...) modifies it at the same time" (Goya 1995: 7), is inspired by the Andalusian duende, a spirited passion said to underlie local music and dance: "Spain is, at all times, stirred by the duende, country of ancient music and dance" (García Lorca 1933). Writing on Tradition and the Individual Talent, T.S. Eliot says that: "What is to be insisted upon is that the poet must develop or procure the consciousness of the past and that he should continue to develop this consciousness throughout his career" (Eliot 1919: 55).

This can be contrasted with their contemporary early Modernist artists and architects who believed that, for example, "the construction of pictures has hitherto been foolishly traditional" (Chipp 1970: 289), or "Architecture

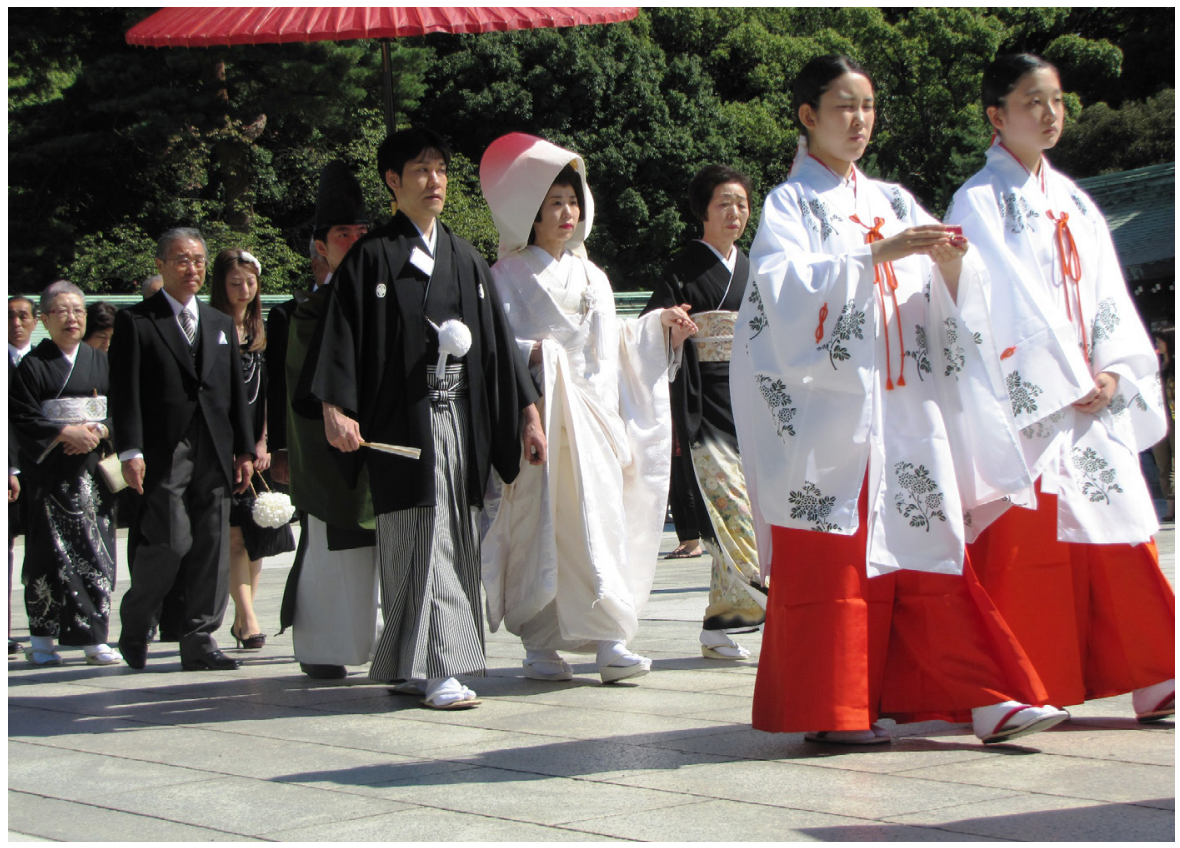

Figure 6. A Japanese Wedding: Key community and family ceremonies often include symbolic reference to ancient traditions (Creative Commons, Eli Shany) 
in effect, a sub-set of most national and local communities. At a popular level, it is well attested (Ghomeshi et al 2013) that the majority of people have as part of their identity the traditional architecture of their nation or region.

There is one handicap to the overt recognition of being "traditional", the misunderstanding that this tradition is simply history. A better understanding of tradition as a phenomenon can moderate the restrictions that this creates. Tradition, as memory, is never precise. While it may be quite acceptable to create work that could be, to a relatively untrained eye, mistaken for an historical work, it is not a necessary condition for it to be part of the tradition to which that historical work belongs. This knowledge releases traditional design to adapt creatively to modern conditions, as indeed it always has, and this removes any objection that these traditions cannot respond to new functions, materials or technologies (Figs. 11 and 12). In the manner of all traditions, this will be an evolution and it will retain a clear and identifiable relation to its origins. The quality of this evolution, the avoidance of a degeneration of the tradition, is that this path will be recognisable to the smaller community of traditional artists and designers who are knowledgeable participants in its ancestry.

\section{Conclusion}

A full understanding of tradition as a universal phenomenon should be informative to architects and urban designers who self-identify as traditional. Tradition is much more than the reproduction of history and its importance lies in its role as a vital means of maintaining the identity of communities. This role explains the passions it can arouse in both the design professions and the wider communities who see their identity threatened by the visual erosion of the traditional places with which they identify. Equally, the absolute insistence of Modernist designers that their work cannot be mistaken as traditional is explained by the urgent need to signal their membership of their community, which they present as always under threat from the wider community and requiring solidarity to survive. It is just a paradox that their history is based on a denial of any adherence to a tradition when, in fact and inevitably, they are identified by their own traditions. Finally, there can be no moral choice between protecting the identity of wider communities with the places they call home, as a contrary to imposing the traditions of a community that has a declared lack of interest in those of the wider community. Nor can any moral position be claimed based on the freedom to invent or create; all traditions have a place for innovation and evolution and, as with Modernists as well as Traditionalists, the ancestry of these traditions has to remain visible.
Figure 11. Millennium Pavilion, Hampshire, England, Robert Adam, 2000: An expression of both innovative technology and the classical tradition (Adam Architecture)

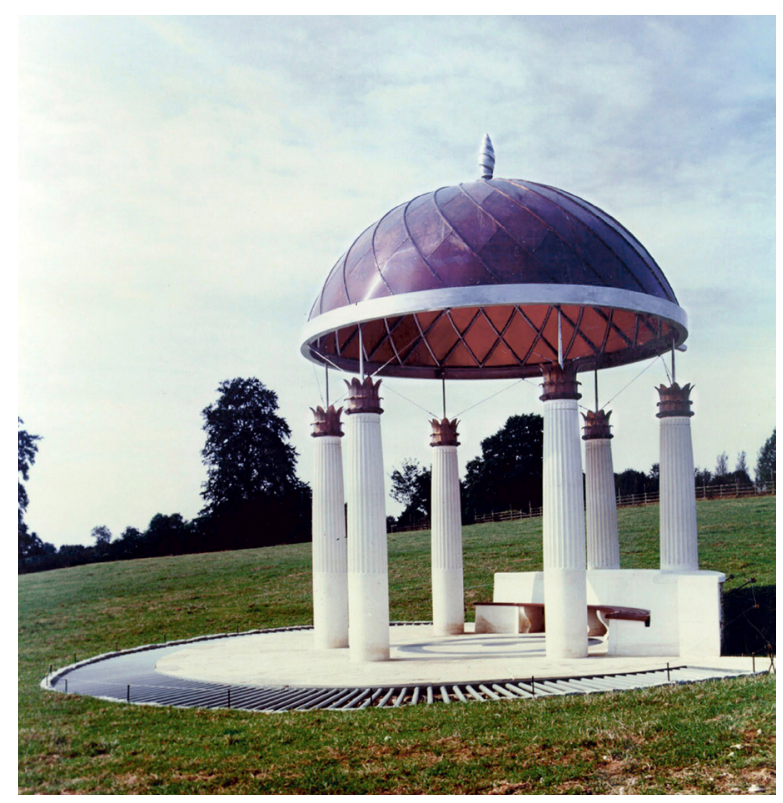

Figure 12. Ashley Park, Hampshire, England, Robert Adam, 2007: A house in the classical tradition but without direct precedent (Adam Architecture)

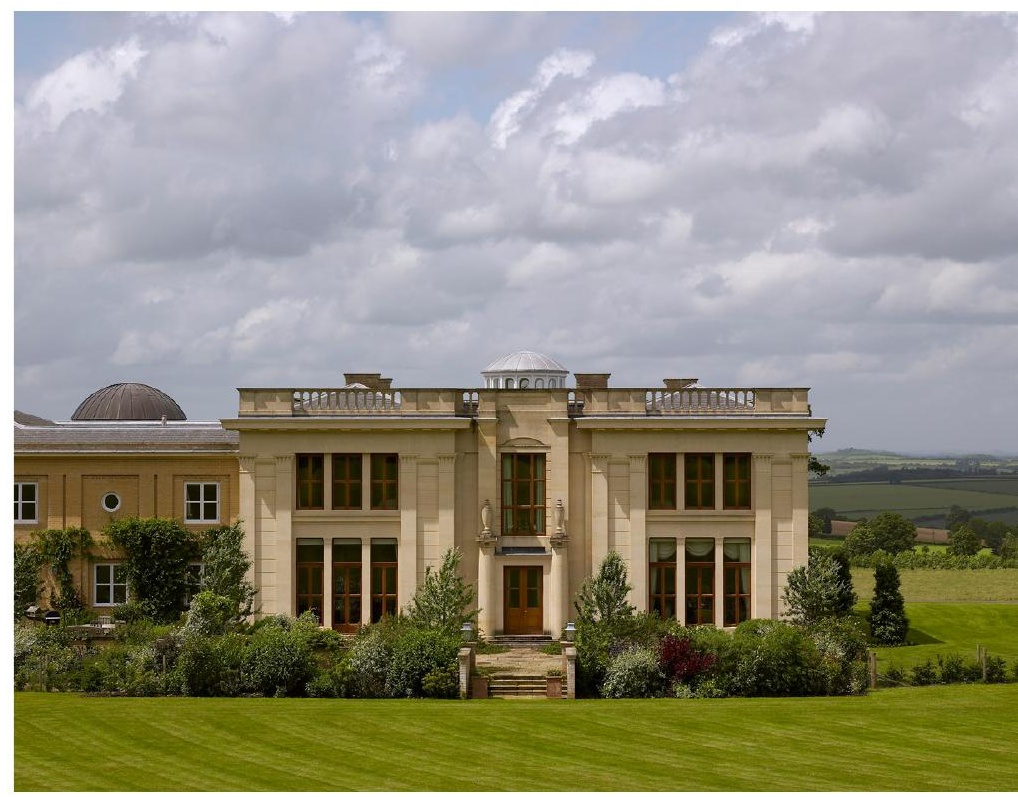




\section{Bibliography $\mid$ Bibliografía | Bibliografia}

Archer, Lucy. 1985. Raymond Erith, Architect. London: The Cygnet Press.

Aristotle (trans.: Stalley, R.; and Barker, E.). 2009. Politics, Book 1. Oxford: Oxford University Press.

Assmann, Aleida. 2012. Cultural Memory and Western Civilization. New York: Cambridge University Press.

Bloch, Marc. 1925. Mémoire collective, tradition et coutume: À propos d'un livre récent. La Revue de Synthèse. Paris.

Boyd, Robert; and Richerson, Peter. 1985. Culture and the Evolutionary Process. Chicago: University of Chicago Press.

Boyd, Robert; and Richerson, Peter. 2005. The Origin and Evolution of Cultures. New York: Oxford University Press.

Chipp, Herschel. 1970. Theories of Modern Art. Berkeley CA: University of California Press.

Cohen, Anthony. 1985. The Symbolic Construction of Community. London: Routledge.

Conrads, Ulrich. 1970. Programmes and Manifestos on 20th-Century Architecture. Cambridge, Massachusetts: MIT Press.

Coser, Lewis (ed. and trans.). 1992. Maurice Halbwachs on Collective Identity. Chicago: University of Chicago Press.

Diderot, Denis; and d'Alembert, Jean. 1993. Encyclopédie, ou dictionnaire raisonné des sciences, des arts et des métiers. Paris: Editions Flammarion.

Eliot, Thomas Stearns. 1919. Tradition and Individual Talent. The Egoist, vol. VI, 4, September/December.

Farrell, Terry. 2004. Terry Farrell - Life and Work - Early Years to 1981. London: Laurence King Publishing.

Farrell, Terry. 2008. Farrells HK: 16 Years of Architecture from London to Hong Kong and Beyond. Walloon Brabant: MCCM Ltd.

Fernyhough, Charles. 2012. Pieces of Light: The New Science of Memory. London: Profile Books.

García Lorca, Federico (trans. Kline, Dennis). 1933. Theory and Play of The Duende. https://www.poetryintranslation.com (consulted on 10/09/2020).

Ghomeshi, Mohammed; Nikpour, Manour; and Jusan, Mahmud. 2012. Evaluation of Conceptual Properties by Laypersons in Residential Façade Design. Arts and Design Studies, vol 3, 13-17. International Institute for Science, Technology and Education.

Giddens, Anthony. 1991. The Consequences of Modernity. Cambridge: Polity Press.

Giedion, Sigfried. 1941. Space, Time and Architecture: the growth of a new tradition. Cambridge, Massachusetts: Harvard University Press.

Gowing, Lawrence; and Sylvester, David. 1990. The Paintings of William Coldstream, 1908-87. London: Tate Publishing.

Goya, José. 1999. Poetic Image and Tradition in Western European Modernism. Comparative Literature and Culture, vol. 1, 2, 1-10. West Lafayette, Indiana: Purdue University Press.

Habermas, Jürgen. 1987. The Philosophical Discourse of Modernity. Cambridge: Polity Press

Heelas, Paul; Lash, Scot; and Morris, Paul (eds). 1996. Detraditionalisation. London: Blackwell.

Hobsbawm, Eric; and Ranger, Terence (eds). 1983. The Invention of Tradition. Cambridge: Cambridge University Press.

John, Richard. 2001. Thomas Gordon Smith and the Rebirth of Classical Architecture. London: Andreas Papadakis Publications.
Latham, Ian; and Swenarton, Mark (eds). 2002. Dixon Jones: Buildings and Projects 1959-2002. London: Right Angle Publishing Ltd.

Le Corbusier (trans.: Etchells, Frank). 1923. Towards a New Architecture. London: Architectural Press.

Lowenthal, David. 2015. The Past is a Foreign Country, Revisited. Cambridge: Cambridge University Press

Mellor, David. 1998. Real Time II. London: Routledge.

Morris, Morgan. 2018. Tradition with a Capital “T”: The Value of Campus Traditions Growth: The Journal of the Association for Christians in Student Development, vol. 17, 17.

Nora, Pierre. 1985. Between Memory and History: Les Lieux de Mémoire. Representations, 26: 7-24. Berkeley.

Olick, Jeffrey; Vinitsky-Seroussi, Vered; and Levy, David (eds). 2011. The Collective Memory Reader. Oxford: Oxford University Press.

Pieper, Josef. 1994. Tradition: The Concept and Its Claim Upon Us. Modern Age, vol. 36, 3: 217-228. Chicago.

Rossi, Aldo (trans.: Ghirardo, Diane; and Ockman, Joan). 1982. The Architecture of the City. Cambridge, Massachusetts: MIT Press

Saint-Just, Louis Antoine. 1793. Rapport au nom du Comité de Salut public: 1er octobre. Paris: Bibliothèque de l'Assemblée nationale.

Shils, Edward. 1981. Tradition. Chicago: University of Chicago Press.

Vidler, Anthony. 1976. The Third Typology. Oppositions 7, 4: 13-16. New York: Princeton Architectural Press.

\section{Biography $\mid$ Biografía | Biografia}

\section{Robert Adam}

He trained at the University of Westminster and in 1973 won a Rome Scholarship. He has practised since 1977 and founded Adam Architecture in 2000. His projects include major private houses, historic buildings, public and commercial buildings and urban design. He is a leading figure in modern traditional and classical architecture, pioneer of contextual urban design, furniture designer, author and scholar. He has written historical, critical and theoretical papers and his books include Classical Architecture (Viking, 1990), The Globalisation of Modern Architecture: The impact of politics, economics and social change on architecture and urban design since 1990 (Cambridge Scholars, 2012) and Time for Architecture: On Modernity, Memory and Time in Architecture and Urban Design (Cambridge Scholars, 2020). He lectures widely in the UK with tours of the USA, Russia, China, Iran and Brazil. 